\title{
COPEPODA: SUMBU KELANGSUNGAN BIOTA AKUATIK DAN KONTRIBUSINYA UNTUK AKUAKULTUR
}

\author{
Media Fitri Isma Nugraha") dan Intanurfemi Bacandra Hismayasari" \\ "Balai Riset Budidaya Ikan Hias \\ Jl. Perikanan No. 13, Pancoran Mas, Depok \\ E-mail: media.fitri@kkp.go.id \\ ") Akademi Perikanan Sorong \\ Jl. Kapitan Pattimura, Tanjung Kasuari, PO Box 109, Sorong 98410, Papua Barat
}

\begin{abstract}
ABSTRAK
Ulasan ini mencoba memperkenalkan dan manfaat jasad renik copepoda untuk domain manusia. Perannya sebagai basal kehidupan akuatik dan taksa vertebrata lainnya sering dilupakan, pada ulasan ini pula akan mengenalkan jasanya pada akuakultur. Copepoda digolongkan dalam Phylum Crustacean, yang berukuran sangat kecil sekitar 60-200 $\mu \mathrm{m}$. Copepoda menghuni hampir setiap lapisan perairan dari permukaan sampai dasar lautan. Jasad renik ini dijadikan sebagai indikator kesuburan perairan, juga sebagai konsumen tingkat pertama yang memberikan gizi berupa EPA dan DHA pada setiap jenis biota perairan. Sejarah manusia pertama kali mengenal copepoda pasca kesuksesan ekspedisi Challenger 1872-1876. Kepedulian kita dalam mengenal spesies ini berarti telah membantu dalam mewujudkan keseimbangan ekosistem. Atas dasar kepedulian dan untuk keseimbangan alam dan lingkungan, maka multi institusional yang bergerak dalam domain akuakultur telah mengoleksi dan mengembangbiakkan satu sub spesies dari copepoda ini di dalam sebuah bak terkontrol, dan dijadikan sebagai sumber pakan alami larva kultivan.
\end{abstract}

KATA KUNCI: copepoda, ekosistem, simbiosis mutualisme, keragaman spesies

\section{PENDAHULUAN}

Planet bumi sebagian besar terdiri atas wilayah perairan. Yang paling luas adalah perairan laut, 2/3 bagian bumi adalah lautan. Semua kehidupan di planet ini berawal dari lautan. Banyak sekali ekosistem yang ada di sana, semua hidup damai dan berdampingan membentuk sebuah simbiosis mutualisme.
Organisme pelagis kecil yang banyak hidup di lautan dan sangat berjasa adalah plankton. Plankton adalah organisme yang tidak dapat mendorong dirinya bertahan terhadap massa air laut (Saiz, 2003). Banyak spesies plankton mempunyai kemampuan lokomotorik, akan tetapi mereka tidak mempunyai kemampuan menahan kekuatan laut, sehingga hidup bebas dan bermigrasi. Plankton laut terdiri atas dua jenis yaitu fitoplankton dan zooplankton. Sebagai perantara antara organisme herbivora dan karnivora adalah zooplankton. Zooplankton laut dapat didefinisikan sebagai semua hewan dan protista plankton yang menghuni lingkungan laut. Pengelompokan ini sangat beragam mulai dari organisme bersel tunggal, vertebrata kecil sampai larva ikan. Hewan yang mempunyai kemampuan bermigrasi secara vertikal dan horizontal ini dikelompokan menjadi 4 kelompok besar yaitu: 1) nanozooplankton dengan ukuran 2-20 $\mu \mathrm{m}$ yang terdiri atas flagellata heterotrofik, 2) mikrozooplankton dengan ukuran 20-200 $\mu \mathrm{m}$. Kelompok ini sangat menarik karena merupakan organisme dalam tahap-tahap perkembangan larva terkecil copepoda, nauplii copepoda dan nauplii dari crustacea lainnya, 3) mesozooplankton dengan ukuran $200 \mu \mathrm{m}$ sampai $2 \mathrm{~mm}$ yang banyak ditemui hampir semua tahapan remaja copepoda dan semua copepoda dewasa, dan 4) makrozooplankton yang terdiri atas udang, larva ikan dan ubur-ubur.

Zooplankton adalah rantai terbesar dan paling penting dalam transportasi energi di dalam lingkungan laut mulai dari organisme autotrof seperti diatom dan flagellata fotosintesis sampai ke predator seperti anjing laut, tuna, hiu, dan paus. Distribusinya yang sangat luas dari 0 meter sampai dasar lautan yang terdalam, tanpa memperdulikan faktor cahaya, suhu, arus, dan ketersediaan makanan. Hidup juga di perairan tawar, sungai-sungai, kolam, dan di lumut-lumut. Dalam hal ketersediaan makanan si kecil ini mampu mengkonsumsi ampas dan sisa kotoran dari makhluk lain, karena bersifat detritus. Sifat inilah yang menjadikan copepoda seperti dua sisi mata uang yaitu 
sebagai sumber nutrisi yang kaya asam lemak esensial karena memangsa lebih banyak diatom (Jiang et al., 2004; Nybakken, 1997) dan juga sebagai penghambat perkembangan amoniak (Kiørboe, 2000). Oleh karena itu, strata hewan mungil ini terletak antara produsen primer (diatom) dan ikan kecil seperti teri dan tembang. Dan tidak diragukan lagi manfaat dan peranan hewan ini sebagai jembatan energi dalam sebuah ekosistem antara fitoplankton (mikroorganisme laut) sampai ke predator (Dagg \& Turner, 1982). González \& Smetacek (1994) dan Sun et al., 2010; mengatakan bahwa lebih dari 505 fitoplankton di samudera dikonsumsi setiap hari oleh copepoda, sehingga memberikan variasi biomassa dan menentukan struktur serta fungsi sebuah ekosistem.

\section{METODE}

Metode yang digunakan dalam penulisan ulasan ini adalah metode kepustakaan di mana berbagai sumber tertulis baik itu buku, jurnal, makalah, dan lain-lain digunakan sebagai bahan referensi.

\section{SEJARAH PERKENALAN MANUSIA DENGAN COPEPODA}

Si kecil ini di Indonesia pertama kali dikenalkan oleh seorang ilmuwan Inggris yang bernama Delsman pada tahun 1939. Dari laporan ekspedisi Challenger tanggal 21 Desember 1872-1876 yang dipimpin oleh kapten George Nares yang berlayar sepanjang 70.000 mil lautan, dengan tujuan untuk meletakkan dasar-dasar oseanografi. Kapten George Nares selama ekspedisi selalu membawa gloria biologis termasyur sampai saat ini dan sangat berjasa di bidang oseanografi dunia yaitu Sir Charles Wyville Thomson dari Universitas of Edinburgh dan Merchiston Castle School, Royal Society of London. Dalam bukunya yang berjudul "Report of The Scientific of the Exploring Voyage of H.M.S Chalenger during the years 1873-1876". Salinan tulisan ini ditemukan juga pada institusi National Oceanografi Centre Southampton dan Dove Marine Laboratory di Cullercoats (wilayah bagian utara Ingris). Thomson melaporkan ditemukannya lebih dari 4.000 spesies baru di lautan yang belum diketahui manusia sebelumnya. Salah satunya adalah copepoda yang mendominasi perairan timur Kepulauan Indonesia.

Sangat dimengerti kenapa dari dahulu sampai sekarang para pelayar dari mancanegara tertarik dengan Indonesia, terutama Indonesia bagian timur yang kaya dan sangat subur dengan hasil bumi dengan berbagai variasi dari darat sampai hasil laut, dari ikan sampai terumbu karang. Selain kekayaan bahari Indonesia juga kaya akan plankton. Kelimpahan copepoda di lautan dapat dijadikan sebagai indikator kesuburan dari lautan tersebut, karena copepoda cenderung hidup pada perairan dengan makrofit yang lebih bersih dengan salinitas tinggi sampai tawar.

Saat ini kehidupan si kecil yang berjasa ini terancam punah, akibat "global warming" atau pemanasan bumi. Dampak dari "global warming" ini yang paling nyata di bidang perikanan dan kelautan adalah naiknya permukaan laut. Bahkan sedikit kenaikan tinggi muka laut akan sangat mempengaruhi ekosistem pantai. Kenaikan 50 cm (20 inci) akan menenggelamkan separuh dari rawa-rawa pantai serta mengakibatkan perubahan arus laut. Perubahan arus laut dan tinggi muka laut ini pertama kali akan dirasakan oleh mikrofauna seperti zooplankton dan fitoplankton. Copepoda merupakan zooplankton yang selalu bermigrasi, baik secara vertikal maupun horizontal (Nugraha et al., 2007). Secara tidak langsung "global warming" mengakibatkan perubahan tingkah laku copepoda bermigrasi lebih jauh atau bahkan tidak bisa bermigrasi sama sekali. Hal ini berdampak terhadap ketersediaan makanan bagi organisme hidup di lautan, karena perantara antara produsen dan karnivora tidak ada. Akibatnya tidak ada ikan kecil dan coral. Jika coral juga musnah maka seluruh kehidupan ikan di lautan akan hilang dan musnah pula. Dampak ini sangat luar biasa besar bagi manusia.

\section{KERAGAMAN SPESIES}

Copepoda merupakan kelompok terbesar crustacean (Levinton, 2001), sehingga dalam jumlah dan biomassa mereka melebihi semua kelompok zooplankton. Sub class copepod terdiri atas 10 ordo (Platycopoda, Calanoida, Misophrioida, Harpacticoida, Gelyeiloida, Mormonillioda, Monstrilloida, Cyclopoida, Poecilostomatoida, Siphonostomaloida) (Mauchline, 1998). Dua ordo pelagic yang terpenting adalah Calanoida dan Cyclopoida dengan jumlah sekitar 2.200 spesies termasuk di dalamnya spesies air tawar dan air asin. Sekitar $75 \%$ pelagis calanoida hidup di air asin dan $25 \%$ lainnya hidup di air tawar (Huys \& Boxshall,1991).

Termasuk ke dalam golongon Meiofauna permanen yang berukuran sangat kecil dan menghabiskan seluruh masa hidupnya di dalam sedimen atau seluruh siklus hidupnya bersifat "meiobentos". Copepoda mempunyai kemampuan untuk merespons pertukaran dan kepadatan jumlah makanan (fitoplankton dan diatom) di lingkungan perairan (Williamson, 1981). Nugraha et al. (2007) melaporkan pada perairan di Teluk Sumberkima Bali, copepoda selalu terdapat di setiap tingkat kedalaman mulai dari 0 meter hingga 30 meter, jenis serta spesiesnya bervariasi untuk setiap ordo (Calanoida, Cyclopoida, dan Harpacticoida). Copepoda [Copepod $=$ cope $=$ oar handle/ tangan dayung dan Podos $=$ foot $=$ oar foot/kaki dayung] 


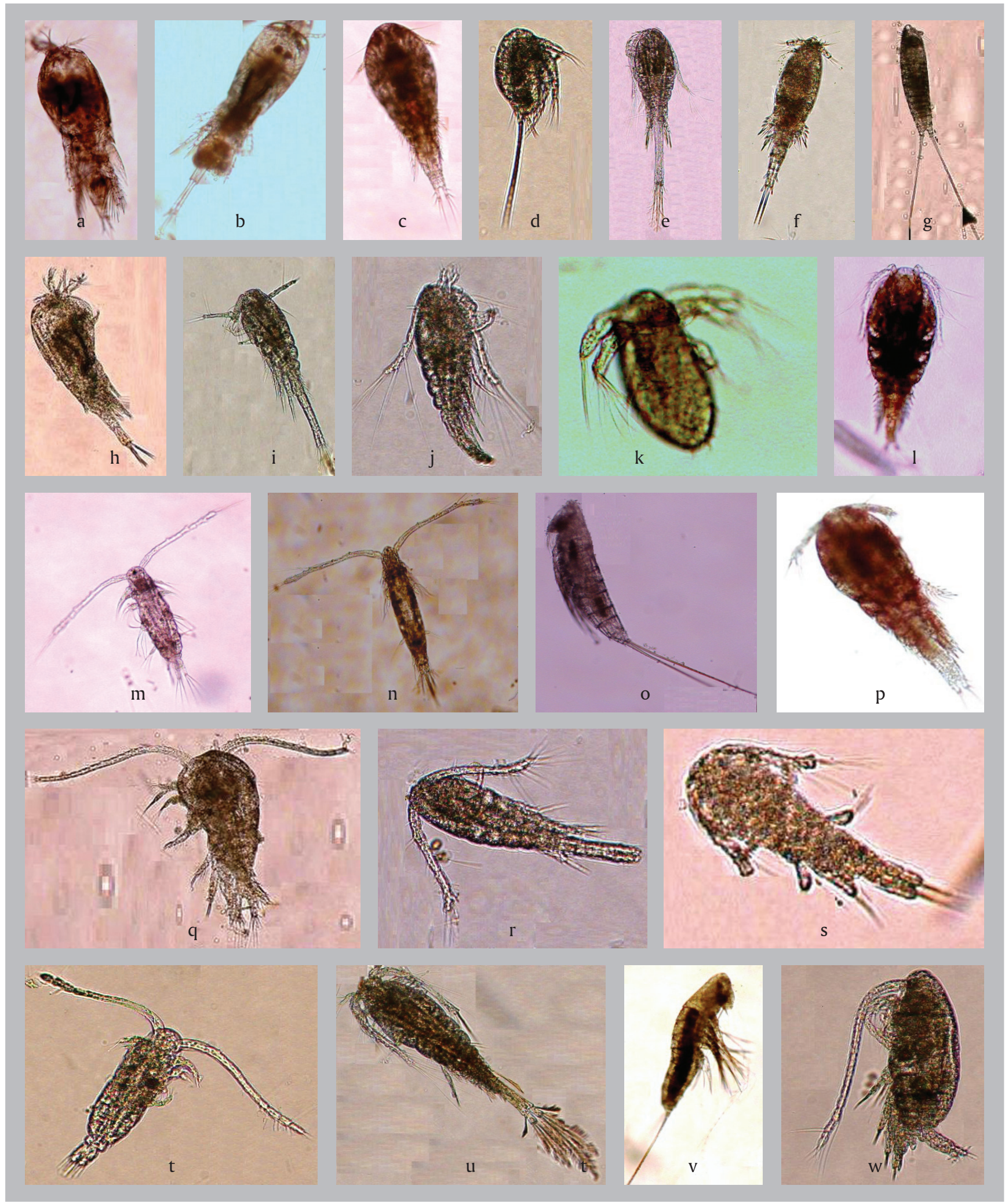

Gambar 1. a) Calanus glacialis, b) Podoplea, c) Oithona nana, d) Lucicutia flavicornis (CLAUS), e) Acartia clausi [betina], f) Acrocalanus gracialis [jantan], g) Macrosetella gracilis (DANA), h) Corycaeus sinicus, i) Oithona similis, j) Euterpina acutifrans, k) Nauplii copepoda, l) Oithona follox [jantan], m) Rhincalanus ornutus, n) Acartia clausi [jantan], o) Microsetella rosea, p) Oithona arvensis, q) Oithona aculata, r) Oithona follox [betina], s) Oithona similis, t) Acartia clausi, u) Paracyclopina nana, v) Acartia Iseana, w) Calanus sinicus. (Foto: @Nugraha, 2007) 
yang berarti zooplankton yang mempunyai tangan dan kaki dayung. Jumlah spesies copepoda adalah sebanyak 1.506, lebih banyak dari jumlah spesies serangga di daratan, sehingga dia dikenal juga dengan nama serangga lautan (Costello, 2000; Humes 1994). Jumlah spesies yang begitu banyak ini digolongkan dalam 10 ordo antara lain Calanoida, Platycopioida, Misophirioida, Harpacticoida, Mormonilloida, Gellyelloida, Monstrilloida, Cyclopoida, Poecilostomatoida, dan Siphonostomatoida. Penyebaran ordo ini tidak merata di setiap perairan dan dibatasi oleh samudera dengan memperlihatkan sebaran geonemy tertentu berdasarkan arus dan gelombang dan toleransinya terhadap habitat. Beberapa spesies copepoda dapat dilihat pada Gambar 1.

Ordo yang umum dibudidayakan untuk pakan larva ikan budidaya adalah Calanoida, Harpacticoida, dan Cyclopoida. Calanoida mempunyai banyak spesies dan mudah diidentifikasi serta mudah diisolasi dari alam.

\section{Calanoida}

Calanoida termasuk spesies yang berperan penting dalam rantai makanan di laut karena jumlahnya berlimpah, kosmopolit, distribusi merata sehingga menjadikannya sebagai salah satu rantai makanan utama bagi hewan laut. Calanoida terdiri atas 43 famili dengan sekitar 2.000 spesies (Boltovskoy et al., 1999). Di perairan laut, Calanoida sangat penting mulai bagi protozoa yang berukuran sangat kecil sampai ikan besar dan bahkan bagi beberapa jenis ikan paus. Hasil survai Sumiarsa \& Nugraha (2009), di perairan Laut Bali utara ditemukan 14 spesies Calanoida di 10 titik sampling di antaranya Acrocalanus gracilis, Calanus minor, C. sinicus, C. tenuicornis, Centropoges abdominalis, Eucalanus attenuatus, Haloptilus longicornis, Lucicutia curta, L. flavicornis, Parvocalanus crassirostris, Pseudocalanus gracilis, Rinchalanus cornutus, Scolecithricella minor, dan Temora turbinata. Spesies yang paling dominan adalah Calanus sinicus. Calanoida mempunyai sifat sangat mudah diisolasi dari alam karena bentuk morfologi yang khas, yaitu bagian tubuh Copepoda Calanoida terdiri atas prosome dan urasome dengan bagian utama terjadi antara lima pedigerous dan genital somitel (gymnoplean position). Urasome terdiri atas empat somite bebas pada betina dan lima somite bebas pada jantan. Pada penyatuan antara somite ini diakhiri dengan caudal rami (duri ekor) (Williamson \& Reid, 2001). Calanoida memiliki 5-6 segmen pada toraks dan cenderung berbentuk oval, serta memiliki antena panjang dan bercabang serta 5 pasang kaki pada toraks. Calanoida betina mempunyai kebiasaan unik di saat sedang bertelur, mereka akan menyimpan telur secara bebas di laut yang kaya dengan nutrisi fitoplankton,

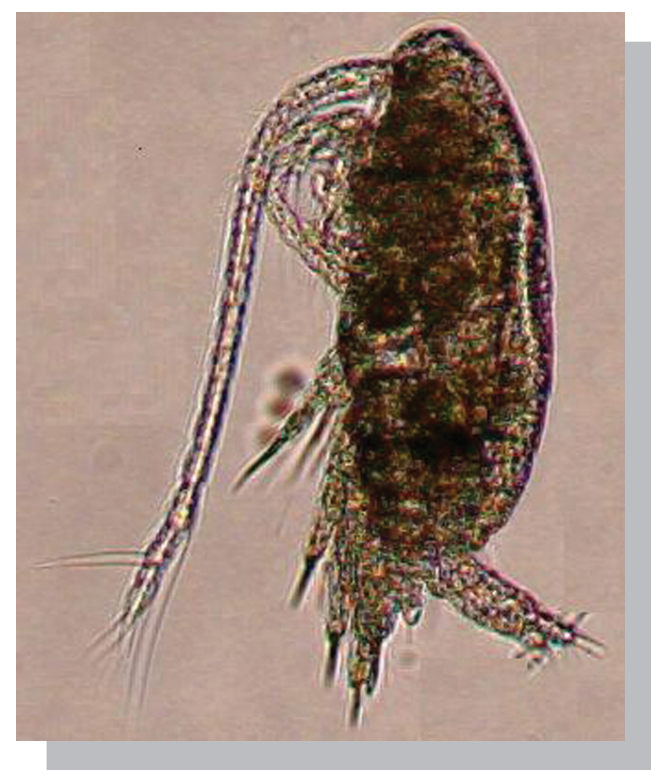

Gambar 2. Copepoda ordo calanoida (Foto: @Nugraha, 2007)

sehingga nauplii yang telah menetas tidak kesulitan mendapatkan makanan, dengan tujuan untuk menjaga kelangsungan hidupnya (Mauchline, 1998).

Ruas dada Calanoida (thoracic) terakhir berkaitan dengan ruas perut (abdomen) dengan sendi yang bisa digerakkan. Ciri yang lebih mudah dikenali adalah antena pertamanya yang panjang, sedikitnya sampai sepanjang badannya. Kelompok Copepoda Calanoida ini adalah yang paling banyak jenisnya. Sedikitnya ada 17 sub spesies yang umum dijumpai. Nugraha et al. (2007) melaporkan ketika melakukan survai di perairan laut utara Bali kedalaman yang berbeda dari $0,5,10,15,20,25$, serta $30 \mathrm{~m}$, Calanoida selalu mendominasi setiap titik survai dan di setiap kedalaman. Secara umum paling banyak dijumpai adalah dari marga Unindula, Canthocalanus, Scolecithrix, Candacia, Eucalanus, Centropoges, Acartia, Acrocalanus khususnya Unindula vulgaris.

\section{Cyclopoida}

Cyclopoida kebanyakan bersifat parasit dan predator serta mempunyai kemampuan berenang pada daerah dengan aliran deras dan sulit, serta mampu melakukan perputaran vertikal dan horizontal, sehingga memudahkan dalam pemangsaan. Beberapa jenis Cyclopoida seperti Mesocyclops dan Macrocyclops bisa dijadikan sebagai agen alami pembasmi insekta terutama nyamuk (Marten et al., 1994; Vu et al., 1998). Sifat Predatori dari Cyclopoida ini sudah dimanfaatkan oleh Balai Penelitian Vektor dan Reservoir Penyakit di Salatiga untuk penanggulangan demam berdarah dengue (DBD) untuk membasmi jentik 


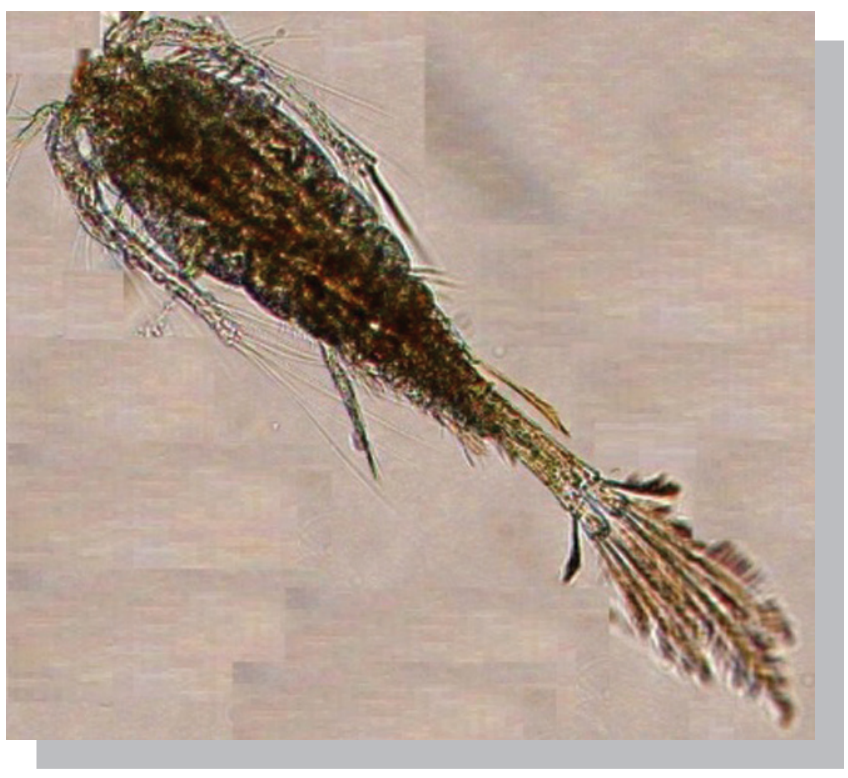

Gambar 3. Copepoda ordo Cyclopoida (Foto: @Nugraha, 2007)

nyamuk. Jenis yang digunakan adalah Mesocyclops (Widyastuti et al., 1995). Hicks \& Coull (1983) mengatakan bahwa Cyclopoida adalah planktonik yang memberikan sumbangan besar bagi biomassa zooplankton di beberapa danau, kolam, dan perairan lautan.

Morfologi Cyclopoida lebih ramping dan panjang daripada Calanoida dan memiliki alat gerak sebanyak 4-5 segmen pada toraks. Badan lebih bulat dan antene lebih pendek dari badannya dan kurang bercabang dibandingkan dengan Calanoida. Ruas sendi terdapat di antara ruas dada (thoracic) kelima dan keenam. Kelompok Cyclopoida ini, selain hidup sebagai plankton juga hidup sebagai bentos di dasar laut. Marga yang paling umum dijumpai adalah Oithona, Oncaea, Corycaeus, Copilia, dan Sapphirina.

Cyclopoida betina mempunyai kebiasaan menaruh telur-telur mereka di dalam kantong di badan dan larva menetas langsung ke laut yang kaya akan nutrisi (fitoplankton dan detritus).

\section{Harpacticoida}

Spesies harpacticoida bersifat kosmopolitan banyak hidup sebagai benthik dan jumlahnya berlimpah pada lingkungan interesterial (perairan). Hidup pada lapisan 1-2 cm di atas sedimen. Kelimpahan Harpacticoida sebagai komunitas benthik menambah luas ukuran partikel sedimen serta memelihara ukuran sedimen (Hicks \& Coull, 1983) hanya sedikit yang hidup sebagai plankton. Harpacticoida yang hidup sebagai plankton akibat terlepas dari dasar laut oleh gelombang dan arus, sehingga dia hidup mengembara sebagai plankton. Beberapa famili dari

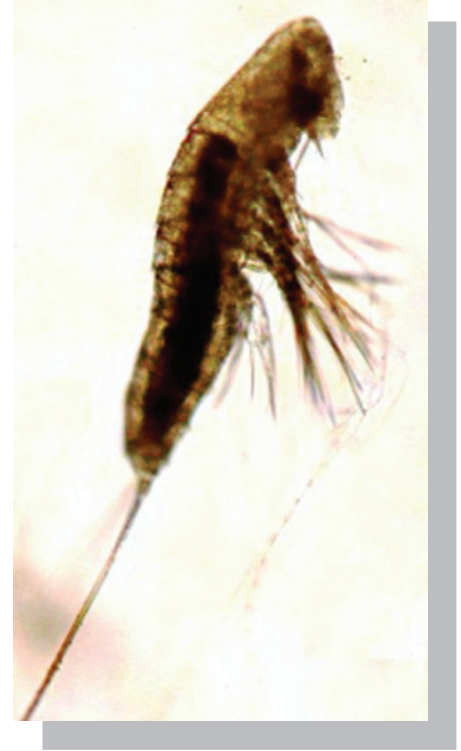

Gambar 4. Copepoda ordo Harpacticoida (Foto: @Nugraha, 2007)

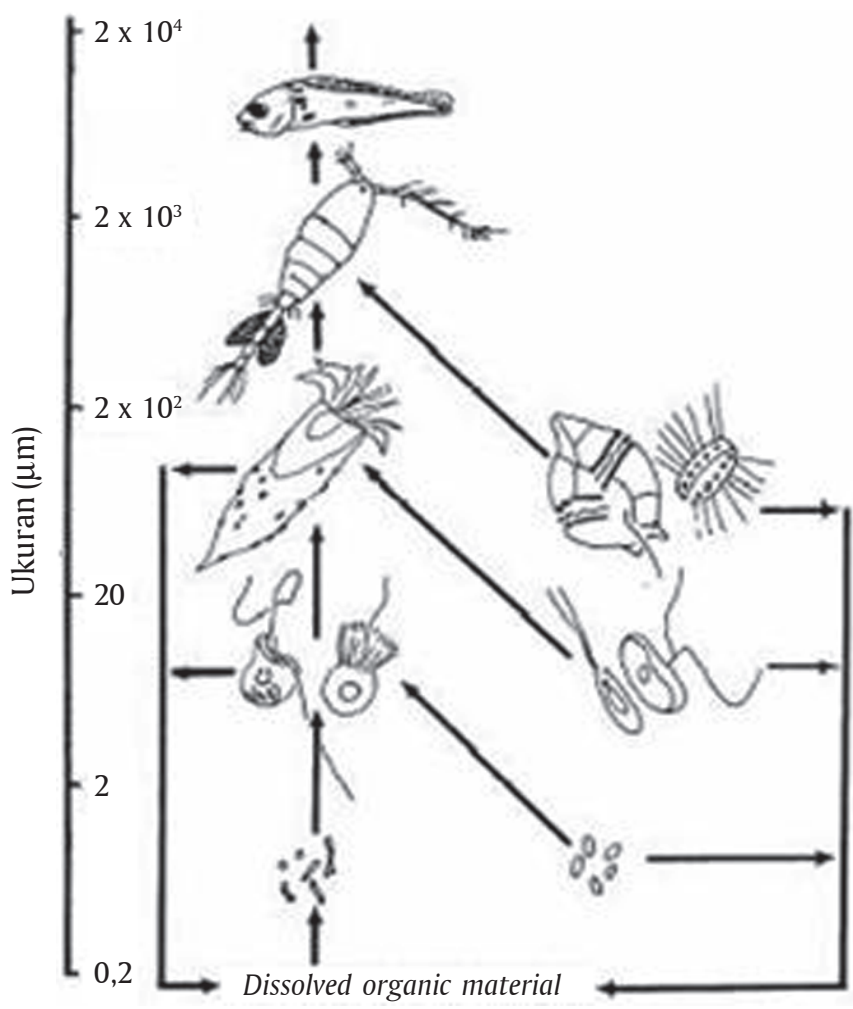

Gambar 5. Skema rantai makanan mulai dari mikroba laut hingga plankton (Fenchel, 1988)

ordo Harpacticoida yang hidup di air tawar, bawah tanah (lumpur dan lumut) antara lain famili Ameiridae, Parastenocaridae, dan Canthocamptidae. Harpacticoida sebagai rantai makanan mempunyai kandungan gizi lebih tinggi dibandingkan jenis lainnya. Morfologinya 
memanjang dan meruncing ke arah ekor. Marga yang umum antara lain: Macrosetella, Clytemnestra, Micracia, dan Euterpina.

Menurut Norsker \& Stottrup (1994), copepoda Harpacticoida umumnya bersifat detrivora (pemakan detritus) dan dapat beradaptasi dengan pakan dari berbagai jenis mikroalga dan juga memakan bakteri (Lavens \& Sorgelos, 1996), lebih toleran terhadap perubahan kondisi lingkungan yang mempunyai produktivitas tinggi dan dapat dikultur dalam kepadatan yang tinggi (Kahan et al., 1982). Berdasarkan hal tersebut maka Harpacticoida sangat potensial untuk dikembangkan.

Secara umum siklus hidup copepoda terdiri atas 11 siklus yang terdiri atas 6 tahapan. Tahap pertama adalah tahap nauplii yang terdiri atas N1-N2, selanjutnya tahap copepodit yang terdiri atas $\mathrm{C} 1-\mathrm{C} 5$ dan selanjutnya tahapan dewasa. Skema siklus hidup copepoda terdapat pada Gambar 6.

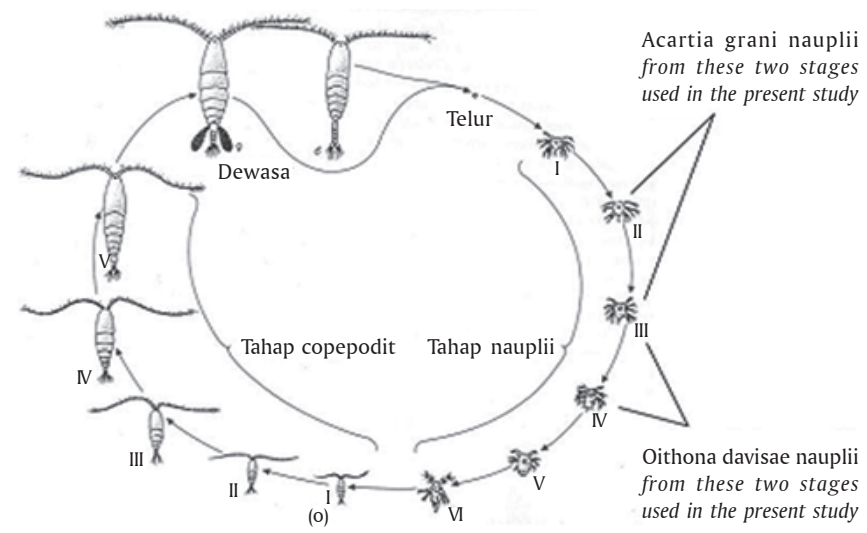

Gambar 6. Skema daur hidup copepod pelagic (Nybakken, 1997)

\section{PERANAN COPEPODA DALAM AKUAKULTUR}

Mengenal lebih jauh Copepoda dan membudidayakannya, berarti kita sudah mencintai mediator terpenting dalam ekosistem perairan yang menopang kehidupan alam semesta. Dalam akuakultur masalah pakan ikan pada masa yuwana adalah masalah utama, akan tetapi masalah tersebut bisa diatasi dengan membudidayakan pakan alami Copepoda spp. mempunyai peranan positif dan negatif antara lain: 1) sumber makanan bagi ikan kecil dan larva ikan, 2) mikropredators ikan dan organisme lain, 3) parasit ikan, 4) intermediate antara inang dan parasit ikan, 5) sebagai inang dan vektor penyakit pada manusia. Copepoda sebagai asosiasi Vibrio Cholera (agen penyebab kolera) telah diteliti lebih dari 25 tahun terakhir. Hal ini bisa terjadi pada saat manusia meminum air yang mengandung copepoda dan tidak dimasak. Selain itu, fenomena blooming alga memacu peningkatan reproduksi copepoda (Piasecki et al., 2004).

Copepoda dari ordo Calanoida, Cyclopoida, dan Harpacticoida adalah sumber makan yang paling penting dalam budidaya perikanan. Copepoda dipilih karena siklus hidupnya yang pendek sekitar 14 hari dari telur sampai dewasa dan mempunyai ukuran yang relatif kecil sekitar 60-220 $\mu \mathrm{m}$, sesuai dengan bukaan mulut larva ikan. Selain itu, copepoda mempunyai gerakan yang zig-zag meluncur pendek dan patah-patah, sehingga lebih menarik perhatian ikan daripada rotifer dan artemia (Lavens \& Sorgelos, 1996).

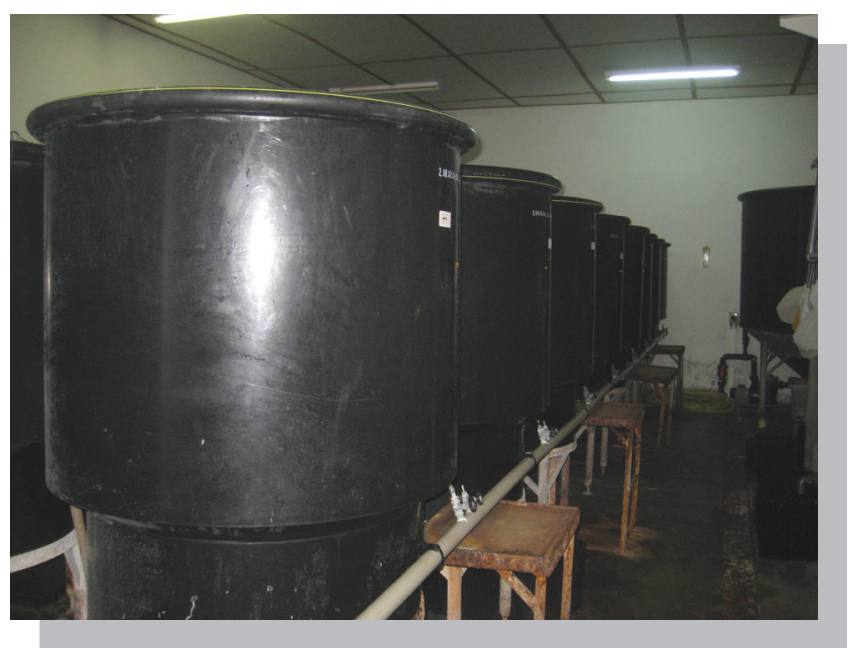

Gambar 7. Bak kultur terkontrol copepoda di Balai Besar Riset Perikanan Budidaya Laut, Gondol, Bali (Foto: @Nugraha, 2007)

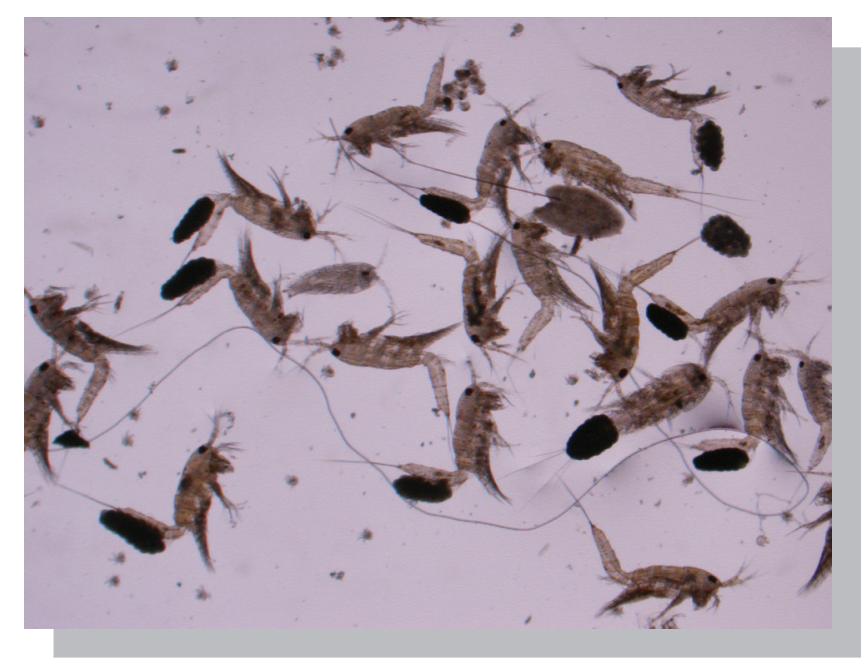

Gambar 8. Copepoda ordo Harpacticoida spesies Tisbe sp. yang dibudidayakan dalam bak terkontrol pada Balai Besar Riset Perikanan Budidaya Laut, Gondol, Bali (Foto: @Nugraha, 2007) 
Pada umumnya jenis copepoda yang dibudidayakan untuk pakan alami adalah ordo Harpacticoida yang bersifat pelagis dan benthik dan kaya akan EPA dan DHA serta tingkat produktivitasnya lebih tinggi dari Calanoida dan Cyclopoida. Balai Besar Riset Perikanan Budidaya Laut, Gondol telah melakukan upaya kultur copepoda Harpacticoida (Tisbe sp.) pada bak kultur terkontrol dengan pemberian pakan berupa fitoplankton (Nannochloropsis oculata, Tetraselmis sp., Chaetoceros sp., dan lain-lain), ragi roti, minyak ikan, dan pelet. Copepoda mempunyai enzimenzim seperti $\Delta-5, \Delta-6$ desaturase dan elongase yang diperlukan untuk mengubah asam lemak esensial rantai pendek (LNA-18:3n3) menjadi kandungan asam lemak esensial rantai panjang DHA (22:6n3) dan EPA (20:5n3), serta omega 3 yang mengandung asam lemak tak jenuh (HUFA) tinggi. Semuanya ini dapat dimanfaatkan oleh larva ikan (Rhodes \& Boyd, 2005). Selain itu, copepoda juga dapat dijadikan sebagai indikator salinitas di dalam bak akuakultur. Jika populasi copepoda sedikit atau berkurang artinya salinitas airnya di luar batas normal. Selain sebagai indikator salinitas, copepod juga dapat meningkatkan daya reproduksi induk, mempercepat pertumbuhan, meningkatkan daya tahan tubuh, serta mencerahkan warna pada udang dan ikan.

\section{TEKNIK KULTUR COPEPODA}

Copepoda yang umum dikultur adalah calanoida dan harpaticoida. Ordo harpaticoda kurang sensitif dan lebih toleran terhadap kondisi lingkungan yang ekstrim yaitu untuk salinitas berkisar antara 15-70 ppt dan suhu antara $17^{\circ} \mathrm{C}-30^{\circ} \mathrm{C}$ serta memiliki tingkat produktivitas yang lebih tinggi dibanding calanoid. Pada modul alih jenjang D4 bidang studi akuakultur (2009) dijelaskan bahwa harpaticoida dikultur dengan menggunakan semi flow through system, dimulai dengan mengisolasi 10-100 copepoda betina dalam 2-40 L air laut steril dengan kondisi kepadatan 1 ind./mL dan suhu $24^{\circ} \mathrm{C}-26^{\circ} \mathrm{C}$ (Anonimous, 2009).

Calanoida dikultur dengan sistem kontinu (continuous system) yang terdiri atas 3 tangki yaitu tangki utama, tangki pertumbuhan, dan tangki pemanenan. Tangki utama menggunakan tangki berkapasitas $200 \mathrm{~L}$ menggunakan air laut steril dan disiphon setiap hari. Kemudian telur dipindahkan pada tangki pertumbuhan dengan kepadatan maksimal 6.000 telur/L. Telur akan menetas sekitar 50\% setelah 48 jam masa inkubasi dan diberikan pakan awal berupa Isochrysis dan campuran antara Isochrysis dan Rhodomonas sp. setelah berumur 10 hari. Setelah 21 hari, calanoid dewasa dipindah ke tangki pemanenan dengan kondisi kultur sama dengan tangki utama (Anonimous, 2009).

\section{COPEPODA SEBAGAI SUMBER WARNA ALAMI IKAN}

Dalam jaring makanan di laut copepoda adalah produsen utama dari astaxanthin, pigmen karatenoid yang merupakan pembentuk warna, dan antioksidan penting. Kualitas astaxanthin dalam tubuh copepoda dipengaruhi oleh jumlah konsumsi fitoplankton dan pakan. Banyak copepoda khususnya yang bersifat mesopelagic dan bathypelagic berwarna orange sampai merah, seperti pada Neocalanus tonsus, di mana pigmen karatenoidnya sangat banyak dari total lipid. Gantin (1982) dan Mauchline (1998) menemukan beberapa spesies copepoda yang mengandung astaxanthin tinggi, spesies tersebut adalah: Centropoges furcatus, Temora turbinata, Unindula vulgaris, dan Pareuchaeta russeli.

Pigmen copepoda terutama terdiri atas astaxanthin bebas dan mono dan diesters dari astaxanthin. Produksi astaxanthin dalam sistem perairan dapat dipengaruhi oleh perubahan dalam dinamika unsur hara yang dimediasi oleh komposisi komunitas fitoplankton dan pertumbuhan populasi copepoda (Nieuwerburgh et al., 2005). Atas dasar itulah copepoda bisa memberikan warna yang cerah pada ikan. Copepoda juga cocok untuk dijadikan pakan alami untuk ikan hias, khususnya ikan hias akuarium karena mengandung astaxanthin untuk warna orange menyolok sampai merah.

\section{KESIMPULAN}

Mengenal lebih jauh copepoda dan membudidayakannya, berarti kita sudah mencintai spesies yang pertama dan yang utama ini dalam menopang kehidupan alam semesta ini serta mendukung program "save our planet" dan "keep global warming" serta menjaga keseimbangan ekosistem perairan. Copepoda dapat dijadikan sebagai pakan alami larva ikan dan sangat menguntungkan karena mengandung EPA dan DHA yang tinggi, serta mengandung astaxanthin yang cukup tinggi. Sehingga copepoda bisa juga dijadikan sumber bahan pewarnaan pada ikan.

\section{DAFTAR ACUAN}

Anonimous. 2009. Penggunaan dan teknik produksi pakan alami: Copepoda. Program alih Jenjang D4 bidang aquacultur (www.fpk.unair.ac.id), 28 Juli 2011.

Boltovskoy, D., Gibbons, M.J., Hutchings, L., \& Binet, D. 1999. General biological features of the South Atlantic. In: Boltovskoy, D. (Ed.). Zooplankton of the South Atlantic. Backhuys Publishers, Leiden, 1,706 pp.

Costello, M.J. 2000. A Framework for an action on marine biodiversiry in ireland. Prepared for The marine institute. 
Dagg, M.J. \& Turner, J.T. 1982. The Impact of Copepod Grazing on the Phytoplankton of Georges Bank and the New York Bight. Canadian J. of Fisheries and Aquatic Sciences, 39: 979-990.

Fenchel, T. 1988. Marine Plankton Food Chains. Ann. Rev. Ecol. Syst., 19: 19-38.

González, H.E., \& Smetacek, V. 1994. The possible role of the cyclopoid copepod Oithona in retarding vertical flux of zooplankton faecal material. Mar. Ecol. Prog. Ser., 113: 233-246.

Hicks, G.R.F. \& Coull, B.C. 1983. The ecology of marine meiobenthic harpacticoid copepods. Annual Review of Oceanography and Marine Biology, 21: 67-175.

Holeton, C., Lindell, K., Holmborn, T., Hogfors, H., \& Gorokhova, E. 2009. Decreased asaxanthin at high feeding rates in the calanoid copepoda Acartia bifilosa. J. of Plankton Research, 31(6): 661-668.

Humes, A.G. 1994. How many copepods? Hydrobiologia, 292/293: 1-7.

Huys, R. \& Boxshall, T.M. 1991. Copepod Evolution. London. The Ray Society.

Jiang, X., Wang, G., \& Li, S. 2004. Age, distribution and abundance of viable resting eggs of Acartia pacifiva (Copepoda: Calanoida) in Xiamen Bay, China. J. of Experimental Marine Biology and Ecology, 312: 89-100.

Kahan, D., Uhlig, G., Schwenzer, D., \& Horowitz, L. 1982. A simple method for cultivating harpacticoid copepods and offering them to fish larva. Aquaculture, 26: 303-310.

Kiørboe, T. 2000. Colonization of marine snow aggregates by invertebrate zooplankton: Abundance, scaling, and possible role. Limnol. Oceanografi, 45(2): 79484.

Lavens, P. \& Sorgelos, P. 1996. Manual on the production and use of live food for aquaculture. FAO Fisheries Technical Paper No. 301, 295 pp.

Levinton, J.S. 2001. Marine Biology. Function, Biodiversity, Ecology. $2^{\text {nd }}$ edition. Oxford University Press.

Mauchline, J. 1998. Advances in Marine Biology. The Biology of Calanoid Copepods. Elsevier Academic Press, 33.

Marten, G.G., Bordes, E.S., \& Nguyen, M. 1994. Use of cyclopoid copepods for mosquito control. Hydrobologia, 292/293: 491-496.

Nieuwerburgh,L.V., Wänstrand, I., Liu, J., \& Pauli. 2005. Astaxanthin production in marine pelagic copepods grazing on two different phytoplankton diets. J. of Sea Research, 53(3): 147-160
Norsker, N.H., \& Støttrup, J.G. 1994. The importance of dietary HUFA for fecundity and HUFA content in the harpacticoid, Tisbe holothuriae Humes. Aquaculture, 125: 155-166.

Nugraha, M.F.I., Sumiarsa., G.S., Hanafi., A., \& Septory, R. 2007. Pola sebaran horizontal copepoda di Perairan Gondol Bali. Pengembangan Iptek Perikanan dan Kelautan Berkelanjutan dalam Mendukung Pembangunan Nasional. Prosiding Seminar Nasional Perikanan dan Kelautan. Fakultas Perikanan dan ilmu Kelautan Universitas Diponegoro. Badan Penerbit Universitas Diponegoro, hlm. 9-17.

Nybakken, J.W. 1997. Marine Biology. An Ecological Approach. $4^{\text {th }}$ edition. Addison Wesley Longman.

Piasecki, W., Goodwin, A.E., Eiras, J.C., \& Nowak, B.F. 2004. Importance of copepoda in freshwater aquaculture. Zoological Studies, 43(2): 193-205.

Rhodes, A. \& Boyd, L. 2005. Formulated Feed for harpacticoid Copepods: Implication for population Growth and Fatty Acid Composition. In COPEPODS in AQUACULTURE Lee, C.S., Bryen, O‘., P.J., \& Marcus, N.H. (Eds.). Blackwell Publishing, p. 61-74.

Saiz, E. 2003. Swimming dynamics of zooplankton, in Marine Ecology, (Ed.) Duarte, C.M. in Encyclopedia of Life Support Systems (EOLSS), EOLSS Publishers, Oxford, UK.

Sun, S., Huo, Y., \& Yang, B. 2010. Zooplankton functional group sonthe continental shelf of the yellow sea. Deep-Sea Research II 57. Elsevier, p. 1,006-1,016.

Sumiarsa, G.S. \& Nugraha, M.F.I. 2009. Kelimpahan Copepoda (Ordo: Calanoida) di Teluk Pegametan Bali Utara.J. Ris. Akuakultur, 4(1): 55-63.

Widyastuti, U., Yuniarti, R.A., Blondine, Ch.P., \& Widiarti. 1995. Predasi Mesocyclops terhadap berbagai jentik nyamuk vector di laboratorium. Maj. Parst. Ind., 8(2): 32-38.

Williamson, C.E. 1981. Foraging behavior of a freshwater copepod: Frequency changes in looping behavior at high and low prey densities. Oecologia, 50: 332336.

Williamson, C.E. \& Reid, J.W. 2001. Ecology and classification of North American freshwater invertebrate. $2^{\text {nd }}$ Edition. Academic press, p. 915-954.

Vu, S.N., Nguyen, T.Y., Kay, B.H., Marten, G.G., \& Reid, J.W. 1998. Eradication of Aedes aegyptii from a village in Vietnam, using copepods and community participation. American J. of Tropical Medicine and Hygine, 59: 657-660. 